\section{International Scientific Journal Theoretical \& Applied Science}

\author{
Eugene Vasil'evna Vinogradova \\ Associate Professor, \\ Candidate of Philosophycal Science, \\ Assistant professor Department of \\ History and Philosophy, \\ State Maritime University Admiral Ushakov, Russia, \\ grape3@yandex.ru
}

Year: $2016 \quad$ Issue: 4 Volume: 36

Published: $30.04 .2016 \quad$ http://T-Science.org

\title{
PEACEFUL COEXISTENCE OF DIFFERENT STATES - ALTERNATIVE APOLOGY WAR IN THE MODERN WORLD
}

\author{
Abstract: The article discusses the need to push the Program of development of international relations based \\ on peace and political solutions to international conflicts. \\ Key words: modern war apology, apology alternative aggression expansion, program of peaceful coexistence \\ of peoples, as a moral victory is a feat of the Soviet peoples, inhumane thinking. \\ Language: Russian \\ Citation: Vinogradova (2016) PEACEFUL COEXISTENCE OF DIFFERENT STATES - ALTERNATIVE \\ APOLOGY WAR IN THE MODERN WORLD. ISJ Theoretical \& Applied Science, 04 (36): 144-148. \\ Soi: http://s-o-i.org/1.1/TAS-04-36-24 Doi: crossef http://dx.doi.org/10.15863/TAS.2016.04.36.24 \\ УДК 94(47).084.8

\section{МИРНОЕ СОСУЩЕСТВОВАНИЕ РАЗЛИЧНЫХ ГОСУДАРСТВ - АЛЬТЕРНАТИВА АПОЛОГИИ ВОЙНЫ В СОВРЕМЕННОМ МИРЕ} \\ Аннотация: В статье рассматривается вопрос о необходимости выдвинуть Программу развития \\ международных отношений на основе мира и политических решений международных конфликтов. \\ Ключевые слова: современная апология войны, альтернатива апологии, экспансия агрессии, \\ Программа мирного сосуществования народов, победа как нравственный подвиг народов СССР, \\ негуманное мылиление.
}

Заканчивая лихой $\mathrm{XX}$ век, человечество надеялось, что две мировые войны - самые кровавые в истории человечества, да атомная бомбардировка Хиросимы и Нагасаки стали той «каплей», которая переполнила чашу терпения и направила мысль человека на перспективу отыскания нового мироустройства без войн и с ликвидацией ядерного оружия. Люди мечтали о гуманизации отношений между людьми по законам нравственности. Правительство СССР в свое время выступило с Программой мира между государствами с различным общественным строем. Полагали, что XXI век станет таким временем, когда войн на Земле не будет. Увы, прогноз не сбылся, и все 15 лет нового века полны конфликтов и региональных войн. Многие специалисты считают это время «ползучей 3-й мировой войной. Налицо очередной кризис цивилизации. Ответом на кризис возникло несколько вариантов стратегии выживания: северо-американская - экспансия интересов и ценностей США на основе военного, финансового, информационного и технологического доминирования, отсюда и экспансия агрессии, развязывания конфликтов в богатых природными ресурсами регионах мира.

Есть и европейская модель - экспансия интересов и ценностей европейской цивилизации через политическую и экономическую интеграцию. Вот и заманиваются малые страны Европы в свои сети Германии, Англии, Франции, и которые обирают их, загоняют их в огромные денежные и иные долги, затем поглощают их как тот Левиафан. Юмористы, например, говорят, что хороша страна Греция, здесь много культурных ценностей, но и наличествует здесь, увы, огромный денежный долг.

Имеется и китайская модель - стратегия экспансия национальных интересов и ценностей китайской цивилизации посредством этнической миграции, формирования и контроля на планете локальных китайских национальных общностей. 
Очень хитроумная позиция. Есть и арабская стратегия - экспансия интересов и ценностей арабской цивилизации через демографический рост и пропаганду исламских религиозных ценностей.

А Россия? Она не занимается экспансией, но а политическая стратегия государства базируется на «двух китах» - православии и политики ядерного сдерживания, коллективной безопасности, опора на ООН, а национальной идеи нет и государственной идеологии тоже нет. Власть это ставит себе в заслугу, а заслуги здесь нет. Опора же на религию, которая не является религией всего общества, поэтому не может претендовать на государственную идеологию, а в политической и экономической стратегии власть опирается, как правило, не на интересы народа, а на корпоративные интересы меньшинства, и как следствие, происходит отчуждения власти от народа, народа от власти. [2 - С.23]

Такое состояние может привести общество к социальному взрыву и хаосу. Такой вывод делает автор статьи «Общество и глобализация» В. Левашов. [2] И далее подчеркивает, что ситуация в мире в целом и в России в частности опасная и критическая. Статья написана в 2005 году. Что же произошло после 2005 года? Америка с помощью своих саттелитов последовательно и планомерно дестабилизирует обстановку в различных регионах земного шара: Югославия, Ирак, Ливия, Судан, Сирия, а теперь наносится удар по Украине. А Украина это не просто ближнее для нас зарубежье - это уже удар, как говорится, ниже пояса. США недвусмысленно вовлекает Россию в мировую войну. Уже в то время проамериканский президент Украины Ющенко с помощью своих идеологических пособников насаждал в стране махровый национализм, политику русофобии, политику вырывания у людей русскости своих душ. Но что будет с человеком, если сломать стержень его души? То это уже и не человек, а отребье, ибо у него вместо души, нравственности сидят одни материальные потребности - плотские потребности низменного плана. И такому истукану без души можно впаять все что угодно. Отсюда всякие извращения в мировоззрении и извращенное понимание мира, в том числе причин и итогов II Мировой войны. Наблюдается в мировом масштабе грубое, циничное, извращенное толкование исторических событий и итогов II мировой войны. Куда же смотрели все эти годы наши политологии? Куда смотрела вся наша власть? Как могли прозевать события на Украине, развивавшиеся по уже знакомому всем сценарию? События 2013 года упустили, когда без войны Украина развалилась бы сама на 3 части. Да ведь в свое время эти части были искусственно сконструированы как то не очень грамотно геополитически, экономически и этнически. Теперь наблюдаем жуткую ситуацию, ставящую Россию перед необходимостью принятия того решения, к которому ее последовательно толкала и толкает Америка - к войне. Что же, опять кровопролитие безвинных, а виновники войны будут потирать руки? То есть получается, что впервые за последние 20 лет Россия проявила свою волю, свою суверенность, и сразу же последовали санкции, но поможет ли России эта воля для того, чтобы отстоять в полной мере свои интересы без ввязывания в войну? Вот каковы безрадостные итоги, с которыми Россия встретила 70-летие Победы над гитлеровской Германией.

Народ России заслужил свою Победу, положив на плаху 27 миллионов человеческих жизней. Война для страны была великим испытанием и страна, народ выдержал это испытание. Народ, действительно, одержал Победу над грозным и сильным противником. Вспомним, что нападая на СССР, Германия знала, что она по военному и экономическому потенциалу превосходила в начале войны СССР в 10 раз. Поэтому понятны ее успехи в начале войны. Но Советский Союз сумел за 2 года создать новую сильную экономику, новую военную технику, создать самую мощную в мире армию и стала последовательно громить врага, сначала очистив от него свои территории, а затем уничтожив противника в его логове. Это действительно был великий подвиг народа, как на передовой, так и в тылу. Это была Победа вопреки всякому здравому смыслу, но это был гениальный по своему масштабу героизма, самопожертвование народа, его огромное желание уничтожить ненавистного, безжалостного и злобного врага. Как сказал В. Путин, в Великой Отечественной войне дорога Победы была вымощена делами и телами солдат. И логический ее результат в том, что это была война как великая битва за будущее всего человечества. [6]

Но некоторым силам в мире не нравится такой расклад. И опять стервятники обложили Россию со всех сторон и толкают ее в новое кровавое месиво войны. Как и раньше, ни одна из стран - поджигателей не хочет воевать сама без России, ибо как всегда эти страны: Англия, США, Германия хотят воевать руками России. Так, например, в статье «О расчленителях России», написанной в 1949 году, И. А. Ильин писал: «Не следует закрывать себе глаза на людскую вражду, да еще в исторически-мировом масштабе. Не умно ждать от неприятелей доброжелательства. Им нужна слабая Россия, изнемогающая в смутах, в революциях, в гражданских войнах и в расчленении. Им нужна Россия с убывающим народонаселением... Им нужна Россия безвольная, погруженная в несущественные и 
нескончаемые партийные распри, вечно застревающая в разногласии и многоволении, неспособная ни оздоровить свои финансы, ни провести военный бюджет, ни создать свою армию, ни примерить рабочего с крестьянином, ни построить необходимый флот» [4 - С.203]. И далее он говорит, что единая Россия им не нужна! Ибо «единая Россия есть национально и государственно сильная Россия, блюдущая свою особенную веру и свою самостоятельную культуру. Все это решительно не нужно ее врагам» [3 - C.255]. Но может, в конце концов, не надо идти у этих недругов на поводу? Воевать в XXI уже просто неприлично, ибо это будет проявлением негуманного, варварского мышления. [4 - С.98]

Народ России - народ победитель, и заслуженно празднует свою Победу. Но это не значит, что народ России хочет новой войны, даже если она будет носить победоносный характер. И здесь нельзя согласиться с господином Э. Лимоновым [7], который утверждает, что народу нужна еще одна победа, ибо он такой особенный русский народ. Думается, что Лимонов не знает наш народ. У народа нет желания и инстинкта вести войну, напротив, люди, прошедшие Великую Отечественную войну, готовы были заплатить еще одну высокую цену - голод, холод, нищету, отсутствие жилья «лишь бы не было войны» - так они говорили в 40-60 годы XX века.

Но можно согласиться с Э. Лимоновым в другом, что люди в Украине, то есть в Донбассе, Луганске, на юго-востоке Украины не просто русскоговорящие люди, а это русские люди и их судьба - это наша общая судьба. Увы, геополитическая кутерьма в свое время с присоединением русских земель к Украине имеет теперь роковые последствия. Поэтому вывод можно сделать такой, что власть предержащие должны осторожнее разбрасываться «кусками» российских территории, преследуя свои узко индивидуалистические цели, как бы со своего плеча небрежно бросая совсем недружественным странам в угоду их властям русские земли. Надо помнить, что власти ничего не принадлежит, а принадлежит народу, и за каждую пядь земли она должна отчитываться перед народом, ибо подлинным субъектом истории является не кучка безответственных чиновников, а сам народ. Так считал Алексей Хомяков. [9;10]. Он говорил, что единственным «действователем истории» является сам народ. Об этом писал и Маркс [5]. И история тому свидетельница - Победу в Великой Отечественной войне одержал не Сталин, не Жуков и т.д., а народ. Есть еще и такая проблема, и такой вопрос - а есть ли внутри России силы, желающие втравить страну в горнило войны? Мой оппонент Лимонов, само собой, так считает, хотя он понимает, что России нужен мир и общественный строй вроде латиноамериканского социализма, который бы справедливо перераспределил богатства страны между гражданами. Однако, по его мнению, Путин никогда этого не сделает. [7 - С.3] Это было бы, наверное, справедливо и для народа жизненно важно. И сам Путин знает и понимает, что проблему кардинального улучшения жизненного уровня людей давно надо было решать и решить. Но Украинский кризис, в котором Россия увязла, не дает пока надежды улучшения жизни своего населения. Да и само экономическое положение России скорее всего отчаянное, ибо существует экономическая блокада России, поэтому нужны экстраординарные меры спасения страны, но никто эти меры не планирует и пускает дело спасения страны на самотек. Нет во власти настоящих реформаторов - борцов. Но если в стране застой и прорыва не видится, то выход из ситуации хартия войны видит в войне. Еще Гегель сказал, что «загнивающему обществу нужна очищающая война». Но это плохая перспектива и мы знаем какими потерями досталась нам, хоть и победоносная война.

Член РФО А. Мясников в своей статье приводит доводы немецкого философа $\Phi$. Хофмайстера, поясняющие мысль Гегеля: «Вопервых - война,- замечает он,- порождает общественную солидарность, она позволяет преодолеть дезинтеграцию, разобщенность членов общества. При этом она ослабляет корыстный, себялюбивый дух буржуазного потребительского общества, а так же усиливает бескорыстное служение обществу, возбуждает традиционные идеалы мужества, героизма и самоотверженности». [4] Можно сказать, что такая война нужна США по этому признаку как истинно потребительского буржуазного общества. «Во-вторых, - продолжает рассуждать Хофмайстер, - война ослабляет опасные противоречия между властью как системой легализованного насилия и народом; особенно в период экономических кризисов война позволяет скрыть бездарность действующих политиков и их неспособность проводить назревшие реформы. Втретьих, война заставляет ее участников задуматься о главном, - об общих смыслах жизни, об общем благе. Она очищает сознание от всякого «мусора», случайных и малозначимых интересов; она закаляет волю к жизни через ясное осознание близости и непредсказуемости смерти» [4] Очень интересные признаки и они применимы к Украине и ко всем реформирующимся обществам. И интересно, как поведет себя наша «оффшорная аристократия», управляющая обществом вахтовым методом? Неужели у них появится совесть и 
ответственность за свои антинародные действия? [1-C.5]

Что же касается «потребительского общества», оно, как раз, хочет радоваться жизни без войны, без насилия. В России в 90-е годы началось складываться такое потребительское общество. Однако перестройка, уничтожение производства, сельского хозяйства, медицины прервало этот процесс, а кризис, бездарное руководство привело общество к упадку. Но идеологи продолжали утверждать о том, что мы потребительское общество, т.к. на нефтедоллары закупали продукты за границей, а свое производство губили дальше. Но долго это не могло длиться. США и Западная Европа своими санкциями перекрыли каналы мнимого благополучия, теперь надо поднимать свое производство, свое сельское хозяйство, медицину, науку, образование. Казалось бы, не было бы счастья, да несчастье помогло. Но, как было замечено, правительство Медведева эффективно решать эти задачи не может. Что же делать? Путин призывает всем миром решать эти задачи подъема экономики. Но управленцев, способных возглавить руководство этим процессом в правительстве нет. А народ устал, он хочет мирной счастливой жизни. И народ заслуженно отметил 70-ю весну Победы над Германией. И наши предки, добывшие Победу 70 лет назад, пройдя через страдания и лишения, завещали нам жить в мире, они всегда желали нам мирного неба над головой. И не случайно, что одним из итогов войны явилась идеология мирного сосуществования народов, концепция безъядерного мира. И здесь хочется опять сослаться на немецкого философа Хофмайстера. Он пишет в заключении, что война всегда является результатом политики, точнее, бессилием политиков и современные войны заслуживают всяческого презрения и неумолимого наказания их зачинщиков. [4 - С. 101] Очень разумная и своевременная и современная мысль. Пожелаем нашим политикам, чтобы они еще немного подучились, навострились у своих идеологических противников и больше идеологических битв не проигрывали бы. Конечно, разрешить политическими средствами то, что сейчас сложилось, весьма сложно, очень много времени упущено, но одного все же добились: показали миру, что пора российской унизительной покорности закончилась, Россия демонстрирует желание влиять на мировые события, но на этом пути нас ждут серьезные испытания. А Запад, попрежнему, демонстрирует нам свой оскал.
А насчет того, быть или не быть войне, важно помнить, что война - это не прогулка при Луне. Война - это всегда грязь, пот, кровь, боль, насилие, голод, смерть. Сейчас мы находимся на пороге нового этапа осмысления опыта и значения Великой Отечественной войны. Эта война оценивается исторической памятью нашего народа как событие, как память, прежде всего потому, что это память связана с историей каждой семьи, с самыми существенными и сокровенными сторонами жизни нашего народа. Но это и память о том, что наш народ никоим образом не желает быть мясом в мясорубке, называемой войной. Народ за мир во всем мире. И пора прислушаться к голосу народа.

И стыдно, что народ - победитель через 70 лет после окончания войны живет бедно, зато $1 \%$ населения страны контролирует $71 \%$ национальных богатств, а ведь по Конституции у нас страна является социальным государством. Президент Путин предложил целую программу коренного улучшения жизни населения. Ее оценили в 6 трлн. рублей. Но спустя 2 года чиновники утверждают, что мол, международная остановка не способствует этому и в то же время, за один год число долларовых миллионеров в стране выросло с 84 до 154 тысячи человек. Что, выросло производство? Нет, топчемся на месте. Значит, у нас по-прежнему воруют - и воруют из гос. бюджета. [8 - С.1]

Народ России - победитель грозного внешнего врага попал в крутую зависимость от внутреннего прожорливого чиновника, а ему война - мать родная. Сам-то он воевать не будет! И все же празднование 70-летия Победы в Великой Отечественной войне сыграло свою роль - на весь мир Россия продемонстрировала свою волю и свою нравственную силу, когда на Красную площадь вступил, так называемый, «Бессмертный полк», колонна которого растянулась на много верст, числом в 500 тысяч человек. И такие полки прошли во всех городах России. Это повергло человечество в шок. И теперь можно сказать, что это один из главных итогов Великой Отечественной войны - Память о погибших. Для России она священна. Давая оценку этому событию, Президент В. Путин подчеркнул, что это была энергия Великой Победы, которая поддерживает нас. И теперь ответственность за Россию лежит на наших плечах и, что нас поддерживает в этом нерушимая нравственная опора - Победа в Великой Отечественной войне. [6] 


\begin{tabular}{l|lrl|l|ll} 
& ISRA (India) & $=\mathbf{1 . 3 4 4}$ & SIS (USA) & $=\mathbf{0 . 9 1 2}$ & ICV (Poland) & $=\mathbf{6 . 6 3 0}$ \\
Impact Factor: & ISI (Dubai, UAE) $=\mathbf{0 . 8 2 9}$ & PUHIL (Russia) $=\mathbf{0 . 2 3 4}$ & PIF (India) & $=\mathbf{1 . 9 4 0}$ \\
& GIF (Australia) & $\mathbf{0 . 5 6 4}$ & ESJI (KZ) & $=\mathbf{1 . 0 4 2}$ & IBI (India) & $\mathbf{= 4 . 2 6 0}$ \\
& JIF & $\mathbf{1 . 5 0 0}$ & SJIF (Morocco) & $=\mathbf{2 . 0 3 1}$ & & \\
\hline
\end{tabular}

\section{References:}

1. Delyagin M (2014) Climb again into the pocket. - // Argumenty Nedeli №41 October 2014.

2. Levashov V (2005) Society and Globalization. // Sotsis. - Moscow, 2005

3. Ilyin IA (2016) Our tasks. Articles 1948-1954 gg. Bk. 1 // Coll. Op. a 10-m., Volume 2, p. 203-205, 255.

4. Myasnikov AT (2015) Decaying society needs cleansing war? Philosophically and journalistic criticism of modern apology for war. - // Vestnik RFO №1, - pp.100, 2015.
5. K. Marx and F. Engels (2016) t. 17, pp.344, 350 and others.

6. VV Putin (2016) Speech about the celebration of the Victory in the Great Patriotic War on television.

7. S Ryazanov (2015) Get ahead of ourselves - // Argumenty Nedeli №10, March 2015.

8. Uglanov A (2014) Returning three fatties. - // Argumenty Nedeli №40, 2014.

9. Khomyakov A (1991) Full. cit. Op 2 Vols.

10. Khomyakov A (1988) On the old and new. Articles and essays. - M. 1988 pp. 49. 